\title{
Does bracing alter the natural history of Adolescent Idiopathic Scoliosis?
}

\author{
J Ogilvie*, L Nelson, R Chettier and K Ward
}

Address: Department of Orthopaedic Surgery, University of Utah, Salt Lake City, UT, USA

Email: J Ogilvie* - jogilvie@axialbiotech.com

* Corresponding author

from 6th International Conference on Conservative Management of Spinal Deformities

Lyon, France. 21-23 May 2009

Published: 14 December 2009

Scoliosis 2009, 4(Suppl 2):O59 doi:I0.II86/I748-7|6I-4-S2-O59

This abstract is available from: http://www.scoliosisjournal.com/content/4/S2/O59

(c) 2009 Ogilvie et al; licensee BioMed Central Ltd.

\section{Background}

Orthotic treatment of children with AIS is a generally accepted treatment option. Failure of bracing to halt curve progression has been reported in $20 \%$ or more of patients, and it is known that some curves in children with AIS will not progress even if untreated. Success and failure rates of brace treatment vary considerably.

\section{Purpose}

We reviewed the response to brace treatment in patients who were also analyzed with a DNA-based adolescent idiopathic scoliosis progression test (AIS-PT) and compared this with the natural history of adolescent idiopathic scoliosis without treatment. Our purpose was to document the influence of orthotic care on the outcome at skeletal maturity.

\section{Methods}

Medical records and x-rays were reviewed, and DNA was collected with a saliva sample in two cohorts of Caucasian female AIS patients. A risk of progression score was calculated using 53 genetic markers with utility for calculating the risk of AIS curve progression from $<25^{\circ}$ to $>40^{\circ}$ before skeletal maturity or $>50^{\circ}$ at maturity (1-200). Group A (2442 females) had no brace treatment and their outcome at maturity or surgery was known. Group B (308 females) were brace compliant for more than one year and their curve severity at maturity or surgery was known.

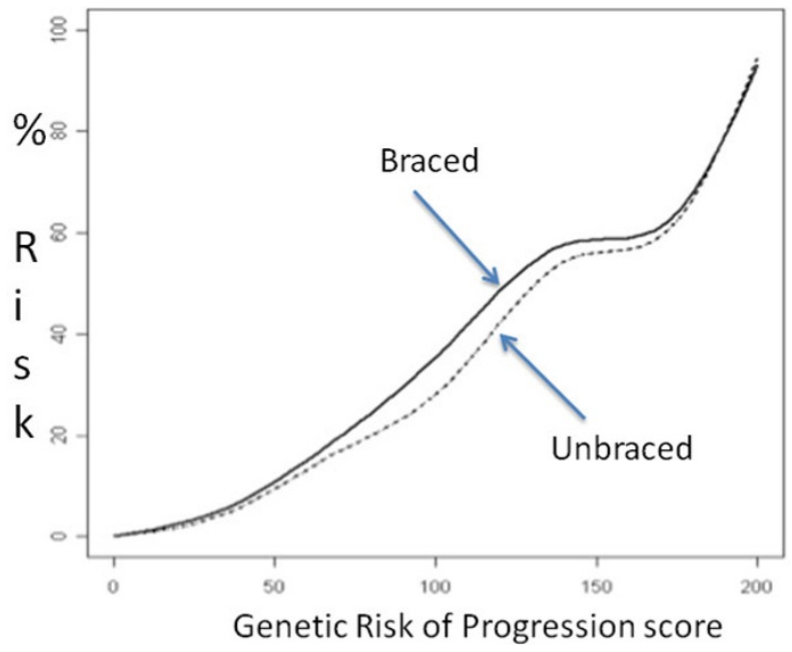

Figure I

\section{Results}

There was little statistical difference in the curves representing risk of progression versus curve severity when the two groups were compared. (Figure 1)

\section{Conclusion}

In this retrospective study of US Caucasian females, there was no statistically significant difference in the natural 
history of adolescent idiopathic scoliosis when comparing bracing treatment and no bracing treatment. At best, there was only a modest brace effect. Prospective trials with genotype homogeneity are needed to validate current assumptions about the efficacy of orthotic types and treatment regimens when bracing adolescent idiopathic scoliosis.

Publish with Bio Med Central and every scientist can read your work free of charge

"BioMed Central will be the most significant development for disseminating the results of biomedical research in our lifetime." Sir Paul Nurse, Cancer Research UK

Your research papers will be:

- available free of charge to the entire biomedical community

- peer reviewed and published immediately upon acceptance

- cited in PubMed and archived on PubMed Central

- yours - you keep the copyright

Submit your manuscript here:

http://www.biomedcentral.com/info/publishing_adv.asp 